\title{
Domiciliary Rehabilitation (Preliminary Report on an Experiment in Self Employment of Disabled Ex-Leprosy Patients)
}

\author{
J. II. RANJITKUMAR AND ERNEST P. IRITSCIII \\ Schieffelin Leprosy Research and Training Centre, \\ Karigiri, North Arcot District, Tamil Nadu 632 106, S. India
}

\begin{abstract}
An experiment in the rehabilitation of patients on the verge of displacement from their families due to economic stringency, is described. The principle is that the patients are enabled to remain in their homes and, as far as possible, resume their previous trades, or take up new trades.

The early results of this experiment are presented. On the whole domiciliary rehabilitation justifies its continuation while greater accumulation of experience will further reduce the failure rate.
\end{abstract}

\begin{abstract}
"Restoration of the handicapped to the fullest physical mental, social, vocational and economic usefulness of which they are capable", is one of the widely used definitions for Rehabilitation (definition issued by the National Council on Rehabilitation, 1942).

Rehabilitation can be effected in a number of ways, depending on the type of disability, availability of funds and specialized personnel and the cultural background of the locality. There could be no hard and fast rule to say a particular type of disability should be handled in a particular way. The whole effort should be directed towards a dehabilitated man being helped to return to self sufficiency.

Nobody ever becomes a beggar from preference. In the first instance he is always driven to it by hunger and need. Leprosy is not a disease of beggars. It is a disease which results in beggars because the community rejects a patient after he has lost his job and hence ceases to he a useful member of it. Domiciliary Rehabilitation aims to assist the patient to remain a useful member of his family and thus avoid the danger of displacement both from his home and from his community. It is well known that, having once become a beggar, it is psychologically extremely difficult for the individual to return to the shackles and bonds of organized society, from the freedom and irresponsibility of the vagrant. To live in society, to be a breadwinner in one's family and to move harmoniously with one's neighbour involves a certain discipline. The beggar has lost the desire for discipline and hence his rehabilitation is very difficult indeed.
\end{abstract}


Domiciliary Rehabilitation aims at the prevention of vagrancy and begging by discovering a person's needs before he is in fact displaced from his own society.

This paper aims to present the early results of what we have termed Domiciliary Rehabilitation where we take not only treatment but also rehabilitation to the homes of our patients.

This project is based on the following assumptions:

The handicapped person will be self-employed and remains in his family who retain responsibility for his care.

The captial cost per work place is limited to the provision of the means of production only, without buildings and other overheads and only with the minimum supervision and assistance if recuuired.

In the case of leprosy patients colonization of the patients in group rehabilitation may have a tendency to perpetuate stigma. This is avoided in a Domiciliary Rehabilitation programme.

\section{Description of the Project}

The Gudiyatham Taluk (total population 418,000-1971 census), has been assigned by the Government to S.L.R. \& T'.C. for leprosy control work since 1964. The total number of registered leprosy patients as on 31 December, 1974, was 8921 . The prevalence rate of leprosy is $21.34 / 1000$ population. The estimated number of patients having advanced (WHO grade III) (WHO Expert Committee on Leprosy, Fourth Report, 1970) deformity is approximately 450 persons, i.e. $5 \%$. Most of them have satisfactory home conclitions. Others are in danger of being rejected from their homes or are a serious burden because they are unproductive. The project concentrated on the latter group and those who have just been dehabilitated. There are two exceptions, who were drawn from the nearby Government Leprosy Beggars Rehabilitation Home.

The aim of the project was both investigation and service.

\section{SURVEY}

It was sought to determine the number of disabled leprosy patients in the Gudiyatham Taluk of N.A. District, Tamil Nadu, who are at present at risk of being displaced from their homes and having to resort to socio-economic dependency, and to assess their employment status and work potential.

\section{REHABILITATION}

The aim was to provide a means of production to the patient ancl/or his immediate family thus restoring him to gainful and socially acceptable employment and to follow up and evaluate the cost effectiveness of different types of aid.

\section{Method of Operation}

One of us went out with the mobile clinic team accompanied by a senior Paramedical Supervisor, to each of the 44 clinics operating in this area. We talked with the patients and the paramedical workers, and sought out any patients who were in an unsatisfactory financial and social position. They were then visited and interviewed in their homes in the village. Their neighbours were also interviewed to get their support, advice and co-operation.

If no other means such as job placement, general advice or counselling could be applied, then, if a suitable aid within the budget was available, the patient was selected for rehabilitation. 
Depending on environmental factors, such as the location of his house, patient's disahility and his aptitude, it was decided whether the patient could be helped and if so what kind of assistance was most useful. The available alternatives were:

Training in handicraft in the centre and then providing the patient with an appropriate means of production.

If the patient was found to have a good practical knowledge of any trade, he could be offered a return to the same trade if possible.

Sometimes livestock or agricultural assistance could be rendered.

A detailed social and occupational history was taken, and was presented to the committee in the centre. The committee consisted of an Fipidemiologist, a Non-medical Supervisor, an Oecupational Therapist and the two authors of this paper. After presentation of the patient's case and discussion, a plan was drawn up based on the discussion which the social worker had had with the patient and his family. If the patient needed training he was admitted for this; care was taken to limit this training period to not more than a month at a time. The patient was then sent home with his loom. He was visited by the Social Worker, where possible, frequently in the beginning and later once a week or month.

To a few, additional assistance has been given by way of provision of raw materials and help in marketing; and to some others (Fig. 1) (the two who had come out of the Government Rehabilitation Home) even a hut had to be provided near the local village for their shelter.
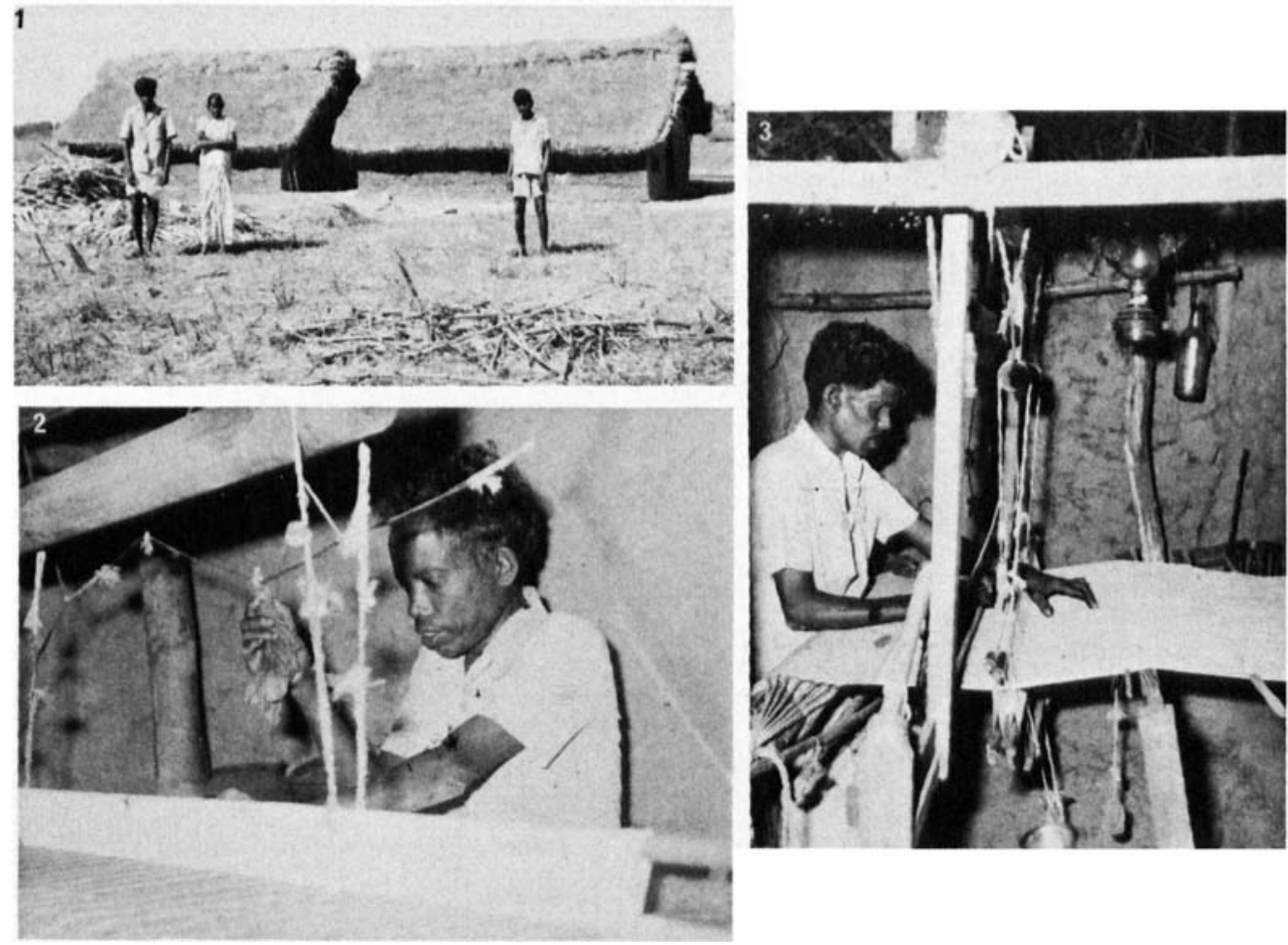

Figs 1 to 3 . 
It was felt undesirable to give assistance away without a contract for return. llence in each case a bond was executed wherein the beneficiary contracted to return the capital in some form or another. In the case of livestock, the patient agreed to return the original animal or its progeny after weaning. In other forms of aid usually they agreed to reimburse the capital by instalments. This was done mainly to make patients feel that they were responsible for their production unit, and also to have a better control over them. A separate file is maintained for each patient with their social and economic history, the committee's decision, the expenditure involved, the bond and notes made during the visits after issue of the units. A special ledger folio is also opened to account for any reimbursements that are made towards the original capital investment.

\section{Results}

\section{NUMBER OF PATIENTS}

The project was planned to investigate and cater to the need of the people resident in the local taluk. However, inevitably as the first patients were being helped, a large number of recuuests, both by post as well as in person came from patients far and near. In many cases these requests for help were recommended by the persons responsible for their treatment and care. Two patients (Fig. 1) came from the nearby Government Leprosy Beggars Rehabilitation Home. They had earlier been our patients and had been trained as weavers before they became heggars. They had no home, and hence, as an experiment, they were included in the project, and were provided with a one-room hut each with a loom installed.

TABLE 1

\begin{tabular}{lr}
\hline Total number of patients investigated & 88 \\
No. of patients assisted: & 16 \\
$\quad$ Domiciliary rehabilitation & 4 \\
Job placement & 4 \\
No. of patients who are in the process of being rehabilitated & 49 \\
No. of patients rejected & 15 \\
No. of cases pending decision & \\
\hline
\end{tabular}

Analysis of reasons for rejection:

TABLE 2(a)

Within Gudiyatham Taluk

\begin{tabular}{llc}
\hline S. No. & Reasons \\
\hline 1. & Investigated and found to be well off & 9 \\
2. Not interested & 6 \\
3. Died while under consideration (T.B.) & 1 \\
4. & 2 \\
& Totyly wanted salaried job & 18 \\
\hline
\end{tabular}


TABLE 2(h)

Outside area

\begin{tabular}{lr}
\hline \multicolumn{1}{c}{ Reasons } & No. \\
\hline S. No. Too far away for investigation or visits & 10 \\
2. In homes, no shelter outside & 5 \\
3. Already rehabilitated by other centres & 5 \\
4. No suitable programme within our limits & 2 \\
5. Irresponsible and no genuine interest shown & 4 \\
6. Only wanted salaried job & 5 \\
& Total \\
\hline
\end{tabular}

\section{Discussion}

\section{RIJECTHD PATIENTS}

From Tables 2(a) and (b) it is clear that Domiciliary Rehabilitation is possible only in selected cases. The indications have yet to be worked out on the basis of the experience derived in the course of time from the assisted patient, but preliminary factors to be considered are:

The patient's desire to work. Patients who were not interested in what we had to offer could obviously not be included.

The patient's initiative to know in what direction he wanted assistance. The best successes were in patients who had a definite request that was within our scope to render.

The patient's courage to face the insecurity of self employment, against the security of a salaried appointment.

Some of the less successful of our selected cases indicate that there are other factors to be considered which have yet to be established.

TABLE 3

Period of follow-up of patients assisted

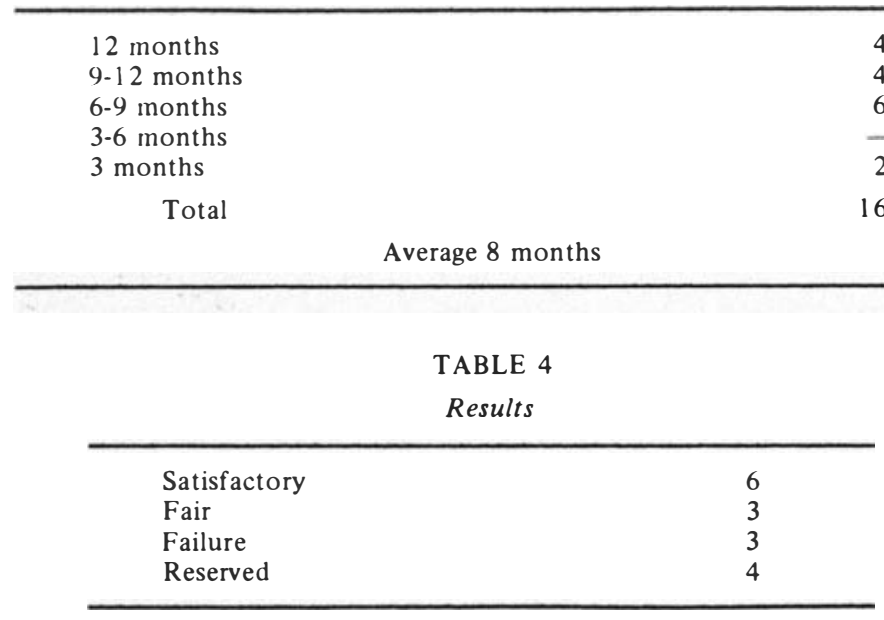




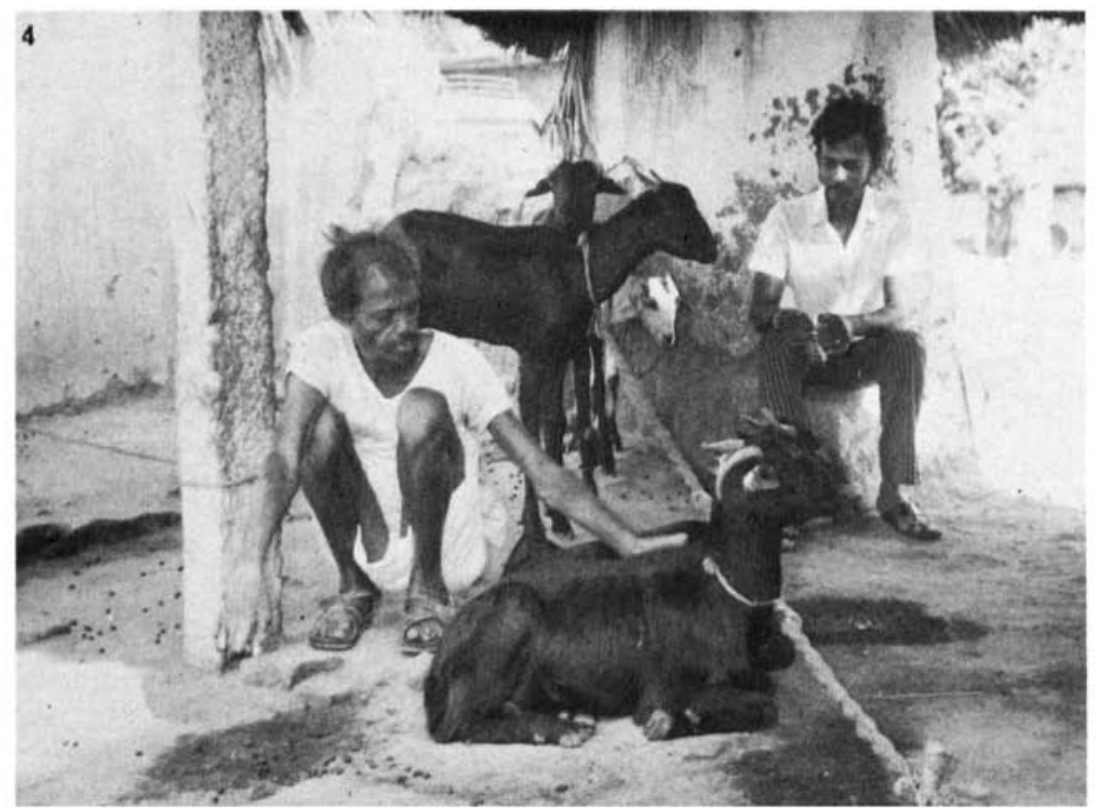

5

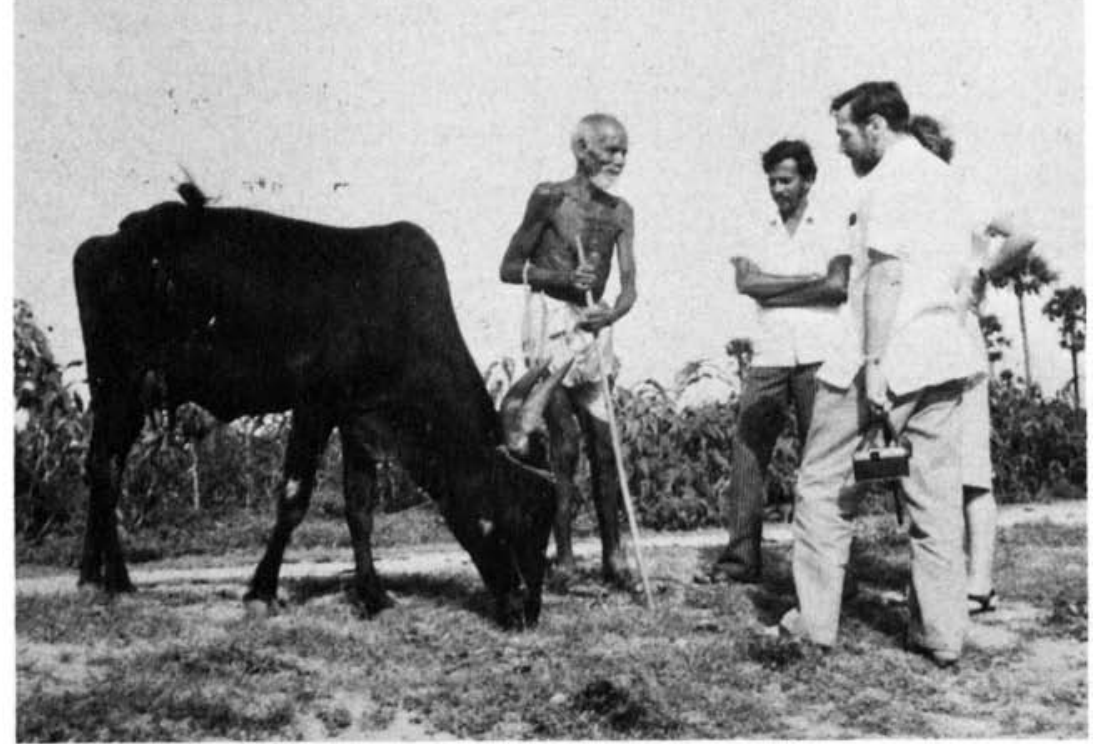

Figs 4 and 5 . 

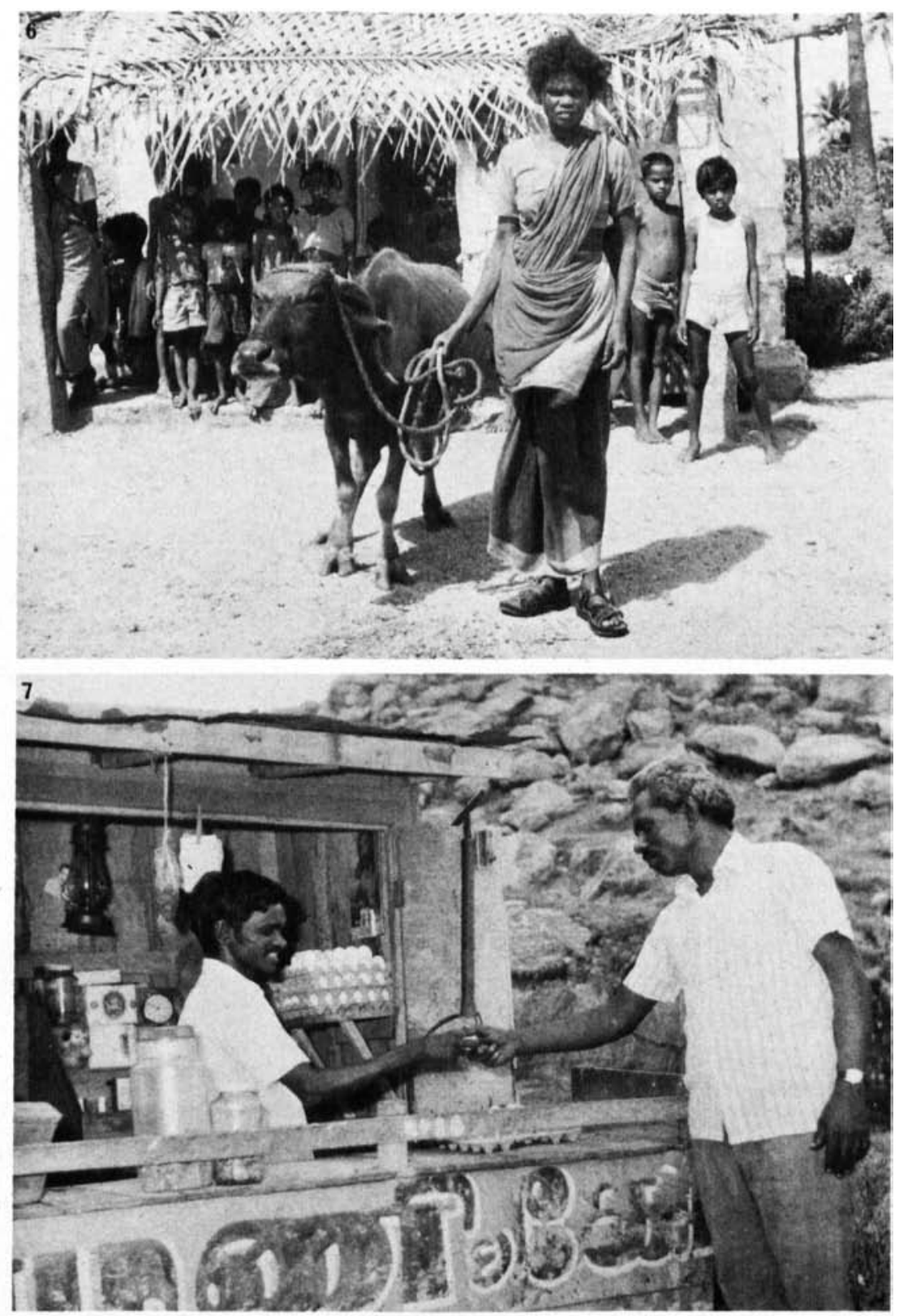

Figs 6 and 7. 


\begin{tabular}{|c|c|c|c|c|c|c|}
\hline $\begin{array}{l}\text { Case } \\
\text { No. }\end{array}$ & Sex & Age & Unit supplied & Date & $\begin{array}{l}\text { Cost/unit } \\
\text { Rs. }\end{array}$ & Previous employment \\
\hline 1 & M & 33 & Standard handloom (Fig. 2) & July 1975 & 430 & Weaver \\
\hline 2 & M & 42 & Standard handloom (Fig. 3) & October 1975 & 430 & Weaver \\
\hline 3 & M & 37 & Bullock cart (second-hand) & December 1975 & 420 & $\begin{array}{l}\text { Bullock cart driver in } \\
\text { Rehabilitation Centre }\end{array}$ \\
\hline 4 & M & 28 & $\begin{array}{l}\text { Bunk shop deposit and } \\
\text { capital for } 1500 \text { eggs } \\
\text { (Fig. 7) }\end{array}$ & January 1976 & 750 & $\begin{array}{l}\text { Started egg business by } \\
\text { himself }\end{array}$ \\
\hline 5 & M & 55 & Four goats (Fig. 4) & July 1975 & 360 & $\begin{array}{l}\text { Was caring for } 3 \text { goats } \\
\text { belonging to somebody } \\
\text { else for } 1 \text { meal a day }\end{array}$ \\
\hline 6 & M & 60 & Silk screen printing unit & September 1975 & 400 & $\begin{array}{l}\text { Silk screen artist and later } \\
\text { admin. asst. in a leprosy } \\
\text { institution }\end{array}$ \\
\hline 7 & M & 42 & $\begin{array}{l}\text { Provision of ploughing and } \\
\text { seeds for his own land } \\
\text { ( } 1 \text { acre })\end{array}$ & July 1976 & 100 & Farmer (owned 2 acres) \\
\hline 8 & M & 60 & Pregnant cow (Fig. 5) & July 1975 & 675 & $\begin{array}{l}\text { Had cows earlier. } \\
\text { Recently wage labourer }\end{array}$ \\
\hline 9 & M & 40 & Pregnant cow & November 1975 & 565 & $\begin{array}{l}\text { Original wage labourer in } \\
\text { oil mill. Recently wage } \\
\text { labourer }\end{array}$ \\
\hline 10 & M & 35 & Pregnant buffalo (Fig. 6) & October 1975 & 412.50 & $\begin{array}{l}\text { Wage labourer. Lived alone. } \\
\text { Domestic servant }\end{array}$ \\
\hline 11 & $\mathbf{M}$ & 49 & Pregnant(?) buffalo & May 1975 & 387.50 & $\begin{array}{l}\text { Unmarried, living with } \\
\text { brother and wife. Father } \\
\text { had had some livestock }\end{array}$ \\
\hline 12 & M & 38 & Purchase of 4 cents of land & January 1976 & 540 & Wage labourer \\
\hline 13 & M & 38 & $\begin{array}{l}\text { Mat loom and training and } \\
\text { house (Fig. 1) }\end{array}$ & January 1976 & 900 & $\begin{array}{l}\text { Beggar admitted in Beggar } \\
\text { Home (learnt weaving here) }\end{array}$ \\
\hline 14 & M & 30 & $\begin{array}{l}\text { Mat loom and training and } \\
\text { house (Fig. 1) }\end{array}$ & January 1976 & 900 & $\begin{array}{l}\text { Beggar admitted in Beggar } \\
\text { Home }\end{array}$ \\
\hline 15 & M & 41 & $\begin{array}{l}\text { Working. Capital for fire- } \\
\text { wood and kerosine oil trade }\end{array}$ & June 1976 & 50 & $\begin{array}{l}\text { Illicit drug and liquor } \\
\text { trade }\end{array}$ \\
\hline 16 & M & 23 & $\begin{array}{l}\text { Cost of cultivation of } 2 \text { acres } \\
\text { land }\end{array}$ & June 1976 & 250 & $\begin{array}{l}\text { Had } 2 \text { acres land. Joint } \\
\text { ownership with brother }\end{array}$ \\
\hline
\end{tabular}


Fire in hut

Patient was a hired weaver, lost job because too slow of disabilities

Discharged from Rehabilitation Centre

Stoppage of local supply. Inadequate capital for advance payment

Poverty

Lost job because of bad vision

1. Repeated hospitalization due to very severe deformities; 2 . land became dry because of reduction in water level

Daughter's marriage necessitated sale of cows

Lost job due to reactions. Progressive deterioration due to deformities

\section{Poverty}

Brother started drinking after prohibition lifted

Threatened eviction from home if he did not buy the land

Wage labourer drifted into vagrancy

Wage labourer drifted into vagrancy

Eviction from family by father

Land leased and patient institutionalized 6 years $\begin{array}{ll}\text { Very satisfactory } & \text { Regular } \\ \text { Very satisfactory } & \text { Slow }\end{array}$

Failure (after 6 months bull died- Nil neglect due to patient leaving home for medical treatment)

Very satisfactory Regular

Satisfactory

Only possible when goats proliferate

Failure (patient absconded leaving equipment behind)

Nil

Satisfactory (patient has now ploughed both acres without assistance)

Not yet. Will pay

af ter present

harvest ( 3 months)

Reserved (delivered a calf but refused to permit milking, so no returns. Cow now pregnant again)

Not yet

Fair (cow gave calf, only slight milk.

Patient now has two more cows to care for. Patient now married and happy)

Reserved (buffalo delivered dead calf. Not yet Now buffalo is pregnant again)

Failure (buffalo proved not pregnant hence animal returned to us)

Very satisfactory

Regular

Fair (frequently off sick, intermittent Not yet work. Wife helps him, just been trained)

Fair (frequently of sick. Remarried, Not yet wife being trained)

Reserved (no follow-up yet) Not yet

Reserved (land is now cultivated) Not yet 


\section{ASSISTED PATILNTS}

Satisfactory. indicates that the expectations of the team have been fulfilled. Fair, is used when the patient's condition and morale have improved but the result is short of our full expectations. Failure, is the term applied when neither the patient nor the team were satisfied. The reserved category is when nc conclusion can be reached yet.

Without any question the best assistance to give is the emergency assistance when the patient has just lost his work. Examples of this are the first two weavers (Case No. 1 and 2-Table 5-Figs 2 and 3).

Those who were living at a bare subsistence level and who could be assisted by increasing capital or facilities also registered as satisfactory. These include the person (Fig. 4) who had the care of someone else's goats and who was given 4 goats for himsell (Case No. 5) and the person (Fig. 7) who had an itinerant egg delivery service and to whom a bunk shop and capital was given (Case No. 4) and the patient whose fields were ploughed (Case No. 7).

The failures are more difficult to analyse because they are due sometimes to misadventure and sometimes to our own inexperience. These include the pregnant buffalo who turned out not to be pregnant (Case No. 11) and the bull which died (Case No. 4). This latter was partly due to the irresponsible behaviour of the patient in leaving his wife alone for more than a month to take care of the bull, while he was admitted in a hospital 100 miles away for ulcer treatment. The case of the silk screen printing equipment is difficult to analyse. The patient had rather poor vision and had produced some very indifferent results in an order we ourselves had given him. Then he absconded and his whereabouts are not known.

\section{COST EFFECTIVENESS}

The most commendable thing about this form of rehabilitation is its cheapness and the fact that the patient is no worse off in the event of failure than he was before. Whereas with other forms of rehabilitation the patient may be still more displaced by virtue of having been removed from his home environment. The average capital investment per work place in our series was Rs.536/-. To this must be added at least a portion depending on the number of beneficiaries, of the salary of a highly skilled social worker, and transport expenses for supervision, interviews, etc. On the whole, it could be said that rehabilitation is achieved at a cost in the order of Rs.1000/- per work place. Compared with the cost of sheltered industry this is relatively insignificant.

\section{Conclusion}

On the whole it would seem that the success of the experiment lies in careful selection of the cases to be assisted.

Rehabilitation has no single solution. For each case the choice has to be made as to which type of rehabilitation is most likely to succeed. The choices now available include:

Job placement where the patient is assisted to find a salaried post. For the educated or skilled with minimum deformity.

Vocational training and sheltered workshop. Employment or subsequent job placement for the younger and more educated group.

Domiciliary rehabilitation for the older and usually rural patient who has not yet been displaced from home. 
After these three possibilities are considered there still remains a group of patients for whom no direct assistance towards self sufficiency is possible and for whom some sort of pension scheme must be considered. Such a scheme will often enable the patient to remain with his relatives and contribute his pension towards his keep. The pension must however be dishursed in small amounts at not greater than weekly intervals and at the most peripheral. level of the administration, namely, the block headquarters. This is in order to ensure that the patient actually remains with his family and does not go to the city to beg.

Probably the most important contribution that this experiment is making is to demonstrate the need for attention to be directed to the prevention of dehabilitation. The patient is now allowed to become community dependent but is assisted at the stage when he may only have become family or neighbour dependent. As in the case of treatment of disease, so in rehabilitation, the earlier the diagnosis, the more effective and the cheaper the treatment.

\section{Acknowledgements.}

This work was undertaken with the assistance of a grant from the Department of Social Welfare of the Governınent of India. The authors would like to convey their thanks to the Department of Social Welfare of the Government of India.

\section{References}

W.H.O. (1970). Expert Committee on Leprosy, Fourth Report. Wld Hlth Org. Technical Report Series No. 459. 